\title{
STURGEON DISEASES IN AQUACULTURE
}

\author{
Vladimir Radosavljevicíc ${ }^{*}$, Vesna Milićević ${ }^{1}$, Jelena Maksimović-Zorić ${ }^{1}$, \\ Ljubiša Veljović ${ }^{1}$, Ksenija Nešićc ${ }^{1}$, Marija Pavlović1, \\ Dragana Ljubojević-Pelić ${ }^{2}$, Zoran Markovićs \\ ${ }^{1}$ Scientific Institute of Veterinary Medicine of Serbia, Belgrade, Serbia \\ ${ }^{2}$ Scientific Veterinary Institute, "Novi Sad", Novi Sad, Serbia \\ ${ }^{3}$ University of Belgrade, Faculty of Agriculture, Belgrade, Serbia
}

\section{Abstract}

Sturgeon aquaculture is economically important in many countries, for both meat and caviar production. Sturgeon is the common name for 27 species of fish belonging to the family Acipenseridae. Among them, only the sterlet (Acipenser ruthenus) and the Siberian sturgeon (Acipenser baerii) completes the lifecycle in fresh water. In Serbia, in the last few years, aquaculture enterprises have shown more interest in farming these fish species. Also, the importance of sturgeon aquaculture grows due to the rapid decrease of wild populations caused by overfishing, water pollution and destruction of habitat. The development of sturgeon aquaculture activities has been accompanied by the disease outbreaks, and possibility of the emergence and rapid dissemination of several infectious disease agents may represent serious problem in sturgeon aquaculture. Several viral, bacterial, fungal and parasitic diseases have been reported worldwide. Due to the limited knowledge about epizootiology and disease control methods, infectious diseases may represent a major challenge in sturgeon aquaculture. Moreover, none of the diseases reported in sturgeon are regulated in the World Organization for Animal Health (OIE) or European Union (EU) legislations. Due to the increasing interest in sturgeon aquaculture in Serbia present study is focused on the most important pathogens that may represent a threat to sturgeon aquaculture in Serbia.

Key words: sturgeon, Acipenseridae, aquaculture, diseases

${ }^{1 *}$ Corresponding author: vladimiradosavljevic@yahoo.co.uk 


\title{
BOLESTI JESETRE U AKVAKULTURI
}

\author{
Vladimir Radosavljevićc ${ }^{1}$, Vesna Milićević1, Jelena Maksimović-Zorić1, \\ Ljubiša Veljović ${ }^{1}$, Ksenija Nešić ${ }^{1}$, Marija Pavlović ${ }^{1}$, \\ Dragana Ljubojević-Pelić ${ }^{2}$, Zoran Marković ${ }^{3}$ \\ ${ }^{1}$ Naučni institut za veterinarstvo Srbije, Beograd, Srbija \\ ${ }^{2}$ Naučni institut za veterinarstvo, „Novi Sad“, Novi Sad, Srbija \\ ${ }^{3}$ Univerzitet u Beogradu, Poljoprivredni fakultet, Beograd, Srbija
}

\section{Kratak sadržaj}

Akvakultura jesetre ima veliki ekonomski značaj u brojnim zemljama, kako za dobijanje mesa tako i za proizvodnju kavijara. Jesetra je uobičajeno ime za 27 vrsta riba koje pripadaju porodici Acipenseridae. Među njima, samo kečiga (Acipenser ruthenus) i sibirska jesetra (Acipenser baerii) provode ceo životni ciklus u slatkoj vodi. Poslednjih godina, u Srbiji postoji veća zainteresovanost za uzgoj ovih vrsta riba. Značaj akvakulture jesetre raste zbog brzog opadanja njihovog broja u prirodi, izazvanog prekomernim izlovom, zagađenjem voda i uništavanjem staništa. Razvoj akvakulture jesetre je praćen pojavom bolesti, a mogućnost pojave i brzog širenja uzročnika zaraznih bolesti može predstavljati ozbiljan problem. Više virusnih, bakterijskih, gljivičnih i parazitskih bolesti je uočeno širom sveta. Zbog ograničenih podataka o epizootiologiji i metodama kontrole bolesti, zarazne bolesti mogu predstavljati veliki izazov u akvakulturi jesetri. Šta više, nijedna od bolesti utvrđenih kod jesetri nije regulisana od strane Svetske organizacije za zdravlje životinja (OIE) niti zakonodavstva Evropske unije (EU). Zbog sve većeg interesovanja za akvakulturu jesetre u Srbiji, u ovom radu je ukazano na najvažnije patogene koji mogu predstavljati pretnju za zapate jesetre u akvakulturi.

Ključne reči: jesetra, Acipenseridae, akvakultura, bolesti

\section{INTRODUCTION}

Sturgeon farming has become an important and rapidly expanding sector of aquaculture worldwide. In the last decade, the farming of sturgeon in Western Europe has increased exponentially. The annual world production is allocated among 4 species: White sturgeon (Acipenser transmontanus), Siberian 
sturgeon (Acipenser baerii), Adriatic sturgeon (Acipenser naccarii) and Russian sturgeon (A. gueldenstaedtii). This applies to both the growing of fry and fingerlings for restocking natural reservoirs as well as the production of table sized fish and caviar for the market. Sturgeon farming has become increasingly important worldwide for the production of caviar and fish flesh, as well as for restoration programmes set up to save endangered wild populations (Bronzi and Rosenthal, 2014). Several species are farmed, among which the most desirable are Russian (otherwise known as Danube) (Acipenser gueldenstaedtii) and Siberian (Acipenser baerii) sturgeons due to their short reproductive cycles and desired products (caviar and meat) (Williot et al., 2001). However, the success of sturgeon farming is heavily restricted due to the paucity of information related to sturgeon diseases and related control methods. It is believed that sturgeons are comparatively more resistant to fish diseases; nevertheless, many studies have shown that their diseases are idiopathic and involve different pathogens. Intensive culture exposes the fish to several sources of stress, such as high stock densities and manipulations that predispose animals to a number of infectious diseases associated with viral or bacterial pathogens (Georgiadis et al., 2000). As in the culture of other fish species, diseases are a principal limiting factor in sturgeon farming. Among them, viral diseases often cause major damage to the industry. Disease control in sturgeon farming is difficult due to lack of knowledge about disease epidemiology and control methods (Ciulli et al., 2016). As a result of more intensive sturgeon aquaculture, infectious diseases that affect the species have emerged.

\section{Viral Diseases}

The intensive breeding of sturgeon has facilitated the emergence and the spread of diseases. To date, several specific viruses have been found in sturgeons. Almost all of them were discovered in sturgeons native to North America, both in the USA and Canada, as well as in Europe, where these fish species were introduced (Raverty et al., 2003, Kelley et al., 2005).Viruses of the Herpesviridae and Iridoviridae families are the major threats for the sturgeon aquaculture and presents the most reported causes of mortality outbreaks in sturgeons (Raverty et al., 2003; Shchelkunov et al., 2009; LaPatra et al., 2014). Among them, the white sturgeon (A.transmontanus) iridovirus (WSIV) and white sturgeon herpesvirus type 2 (WSHV-2, later renamed to Acipenserid herpesvirus 2, AciHV-2) are economically the most significant pathogens, causing up to 95\% mortality in cultured young sturgeon (Watson et al., 1995, Georgiadis et al., 2001, Kelley et al., 2005). 


\section{Herpesviral diseases}

Herpesviral diseases in sturgeons are caused by three viruses, the Acipenserid herpesvirus-1 (AciHV-1), Acipenserid herpesvirus-2 (AciHV-2), and Siberian sturgeon herpesvirus (SbSHV) (Kurobe et al., 2008; Shchelkunov et al., 2009).

\section{Acipenserid herpesvirus 1 (AciHV-1) disease}

Acipenserid herpesvirus 1 (AciHV-1), also known as a white sturgeon herpesvirus 1 (WSHV-1), was initially isolated in 1991, from cultured juvenile white sturgeon (Acipenser transmontanus), in California (USA) hatcheries. Mortality was result of the severe infection of the integument and oropharyngeal mucosa (Hedrick et al., 1991). Histopathologically, the virus causes epidermal lesions and diffused dermatitis. AciHV-1 appears to be less virulent under experimental conditions than is AciHV-2 (Plumb and Hanson, 2011).

\section{Acipenserid herpesvirus 2 (AciHV-2) disease}

Acipenserid herpesvirus 2 (AciHV-2) also known as a white sturgeon herpesvirus 2 (WSHV-2), was first isolated from ovarian fluid of an adult sturgeon and was a cause of mortality in farmed juvenile white sturgeon in North America in the mid-1990s (Watson et al., 1995). Later, a closely related virus was isolated in Russia, suggesting that the Russian isolates may have originated from North America. Mortality in adult fish infected with AciHV-2 was generally less than $10 \%$. Experimentally, the shovelnose and pallid sturgeon were susceptible to AciHV-2 but other species were refractive (Mao et al., 1999). White sturgeon herpesvirus- 2 occurs in older sturgeon with small white blisters which develop into the open lesions on the body surface. These lesions are frequently infected with secondary bacteria and/or ectoprotozoal parasites. Internally, the stomach and intestines are filled with fluid but other tissues appear normal. Wild white sturgeon which was infected with AciHV-2 became listless and stopped eating. Current management strategies for controlling AciHV-1 and AciHV-2 are avoidance of the agent and inspection of potential carrier fish via cell culture assay. Sturgeon infected with AciHV-2 could be prophylactically treated with salt and parasiticides to reduce secondary infections in open ulcers. 


\section{Siberian sturgeon herpesvirus (SbSHV) disease}

Siberian sturgeon herpesvirus (SbSHV) was isolated in Russia for the first time in 2006 from moribund Siberian sturgeon (Acipenser baerii) and bester (beluga Huso huso $\times$ sterlet Acipenser ruthenus hybrid) fingerlings during acute outbreak of disease on a fish farm (Shchelkunov et al., 2009). The infection has been found widespread in cultured sturgeon species in Russia. It is the cause of an acute necrohaemorrhagic skin syndrome complicated by secondary opportunistic infections (fungal, myxobacterial or protozoan) (Shchelkunov et al., 2009). Based on sequence analysis of the viral genome, it is determined that the SbSHV is a potential member of the genus Ictalurivirus within the family Alloherpesviridae under the order Herpesvirales (Doszpoly and Shchelkunov, 2010). Two Russian types of SbSHV (I and II) were isolated, and they differ from each other in four principal marker traits and each of the two has close genetic relationship with one or another strain of North American AciHV-2 species. It was hypothesized that the Russian type I and type II SbSHV may represent two different strains or genotypes of the Acipenserid herpesvirus 2 species (Doszpoly and Shchelkunov, 2010).

\section{Iridoviral diseases}

Iridoviruses have been associated with severe disease and economic loss in fish with more than $50 \%$ mortality. The first iridovirus associated with mortality outbreaks of sturgeon was the white sturgeon iridovirus (WSIV) (Hedrick et al., 1990). Other iridolike viruses have been detected in different sturgeon species in North America and Europe, namely white sturgeon iridovirus (WSIV) (Hedrick et al., 1990, Raverty et al., 2003), Missouri River sturgeon iridovirus (MRSIV) (Kurobe et al., 2010, 2011), shortnose sturgeon virus (SNSV) (LaPatra et al., 2014), British Columbia white sturgeon virus (BCWSV), Namao virus (NV) (Clouthier et al., 2013), and Russian sturgeon iridovirus (Adkison et al., 1998). They can cause a lethal disease of the integumentary system in infected sturgeon, resulting in $>90 \%$ mortality within captive populations. In other instances, they are associated with a chronic debilitating wasting syndrome, resulting in severely impaired growth and reduced survival of fry and fingerlings (Clouthier et al., 2018). In total, nine species of sturgeon in the genera Acipenser or Scaphirhynchus of the family Acipenseridae were found susceptible to one or another virus. Outbreaks of virus disease are associated with stress factors such as rearing density, handling, fluctuations in water temperature, levels, and flow rates (Watson et al., 1998, Georgiadis et al., 2000, 2001). The phylogenetic 
studies revealed that these viruses are only distantly related to Iridoviridae, and are included in a group of sturgeon nucleo-cytoplasmic large DNA viruses (NCLDVs). They do not form part of any currently recognized virus genera or family but do belong to the order Megavirales (Colson et al., 2013). NCLDV group has not formally been adopted by the International Committee for the Taxonomy of Viruses (Clouthier et al., 2015). The sturgeon NCLDVs are present in hatchery-reared and wild sturgeon found across North America and northern Europe (Clouthier et al., 2015), and pose a potential disease risk for strategies designed to aid the recovery of threatened and endangered sturgeon populations worldwide (Clouthier et al., 2018). Data on sturgeon iridolike viruses in Europe are limited despite the increasing importance of sturgeon aquaculture. Iridovirus-like infection has been reported in Northern Europe in Russian sturgeon (Acipenser gueldenstaedtii) associated with mortality (Adkison et al., 1998). NCLDVs outbreaks are frequently reported by sturgeon farmers, but only few thorough investigations have been conducted for these outbreaks. Sturgeon NCLDVs appear to be endemic in populations of Acipenseridae found throughout North America (Clouthier et al., 2015). At present, an accurate picture of the geographical distribution of sturgeon NCLDV infection in Europe is not available. Also, in 2009, frog iridovirus type 3 (FIV3), a wellknown ranavirus provoked an outbreak on pallid sturgeon (Scaphirhynchus albus) in an American hatchery (Waltzek et al., 2014).

Recently, Acipenser iridovirus European (AcIV-E) has been detected in sturgeon populations in Europe. It appears that this virus is closely related to North American sturgeon iridoviruses, in particular with the white sturgeon iridovirus (WSIV) and the Namao virus (NV) (Axen et al., 2018). AcIV-E was detected and associated with clinical disease in different sturgeon species (Acipenser baerii, Acipenser gueldenstaedtii, Acipenser naccari, and Huso huso). Higher mortality due to AcIV-E was recorded in Russian sturgeon compared to Siberian sturgeon - $90 \%$ vs $50 \%$ - suggesting a lower susceptibility to the virus in Siberian sturgeon (Bigarré et al., 2017). Much important information, e.g., pathogenesis, transmission routes, and epidemiology of these viruses, is lacking, making virus and disease control extremely difficult (Axen et al., 2018).

\section{Other sturgeon virus diseases}

\section{White sturgeon adenovirus (WSAV) disease}

WSAV was identified in diseased juvenile white sturgeon between 1984 and 1986 (Hedrick et al., 1985) but the disease has not evolved into a serious 
health problem, and there has not been any report on WSAV since then.

\section{Infectious hematopoietic necrosis virus (IHN)}

Sturgeon are often cultured on facilities that contain other fish species. LaPatra et al. (1995) demonstrated that white sturgeon fry were susceptible to IHNV and that white sturgeons cultured with IHNV-infected rainbow trout had neutralizing antibodies to the virus.

\section{Viral nervous necrosis (VNN)}

Betanodavirus within the family Nodaviridae is the etiological agent of viral nervous necrosis (VNN, also known as viral encephalopathy and retinopathy or VER). The virus infects a large range of host species in more than 50 species of marine and freshwater fish worldwide. Athanassopoulou et al. (2003) reported on the presence of a betanodavirus that infected sturgeon (Acipenser gueldestaedi) in fresh water causing disease with neurological signs.

\section{Spring viremia of carp (SVC)}

Vicenova et al. (2011) reported isolation of the SVC virus in sturgeon with the clinical signs of the disease, which included internal haemorrhages, considerably enlarged bright-red spleen, and greyish-yellow liver showing tiny red spots. The sturgeon isolate was genetically identical to the isolate from clinically healthy koi carp collected from the same aquaculture site.

\section{Infectious pancreatic necrosis (IPN)}

Little scientific information is available to assess whether sturgeon can become infected and develop into potential carriers of IPNV. Only the report from France indicated that IPNV was isolated from 3\% (1 of 34) of a group of Siberian Sturgeon Acipenser baerii (Nougayrede, 1988).

\section{Aquareoviruses}

Aquareoviruses are serious pathogens of aquatic animals. Reovirus particles were observed in diseased Chinese sturgeons, suggesting the existence of primary viral illness (Zhang and Gui, 2012). 


\section{Cyprinid herpesvirus-3 (CyHV-3)}

According to Pospichal et al. (2016) the hybrid between sterlet and beluga seems to be susceptible to cyprinid herpesvirus 3, but the authors could not prove that they can transfer this virus to naïve koi. Also, Kempter et al. (2009) reported that Atlantic sturgeon and Russian sturgeon are susceptible to CyHV-3.

\section{Bacterial diseases}

Few mortality outbreaks have been reported in sturgeon associated with primary bacterial pathogens such as the case of lactococcosis in hybrid sturgeon, Bester (Huso huso x Acipenser ruthenus) (Chen et al., 2012). However, the isolation of bacteria from sturgeon was often reported as a secondary infection or as a consequence of severe stress and high stock densities. Motile Aeromonas infection (MAI) is one of the most common infection in sturgeon (Santi et al., 2019). MAI is usually associated with viral diseases in surviving sturgeon. Motile Aeromonas species have been isolated from sturgeon, generally as a consequence of severe stress and high stock densities or opportunistic, secondary to a primary viral infection. A motile aeromonas septicaemia caused by Aeromonas hydrophila frequently induced considerable losses in Persian sturgeon (Acipenser persicus) fingerlings in northern Iran (Soltani and Kalbassi, 2001) and also in the Harrison river sturgeon in Canada (Raverty and Nikl, 1999). Aeromonas hydrophila as a pathogenic agent has been isolated from Amur sturgeon (Acipenser schrenckii) in China (Meng et al., 2011). Aeromonas hydrophila and Aeromonas veronii were isolated during the outbreak of a disease characterized by haemorrhagic ascites and intestinal and renal haemorrhaging in cultured Chinese sturgeon (Di et al., 2018). In Turkey, Aeromonas hydrophila was detected in Russian sturgeon (Acipenser gueldenstaedtii) as the cause of bacterial haemorrhagic septicaemia and high rate of mortality (Timur et al., 2010). Aeromonas veronii was identified as a pathogen and cause of mortality of Siberian sturgeon (Acipenser baerii) (Ma et al., 2009). Aeromonas veronii was isolated from reared sturgeons in Iran (Gholamhosseini et al., 2018). Aeromonas sobria was isolated from Acipenser gueldenstaedtii and Acipenser baerii in Turkey (Kayis et al., 2017). Pseudomonas spp., particularly Pseudomonas fluorescens, are common worldwide and found mainly in cold freshwater. The infection was reported in Acipenser baerii by Brunetti et al. (2006) and in Acipenser gueldenstaedtii by Kayis et al. (2017). The pathogen Pseudomonas alcaligenes has been identified in Chinese sturgeon (Xu et al. 2015). Streptococcus iniae was isolated from liver, kidney and spleen of the dy- 
ing sturgeons with clinical symptoms during an episode of continuous mortality of cultured hybrid sturgeons occurred on a farm in China in 2012 (Wang et al., 2014). Yersinia ruckeri was found responsible for $10 \%$ mortalities in cultured sturgeon (Acipenser baerii) in France (Vuillaume et al., 1987).

Flavobacterium johnsoniae was isolated from the diseased farmed young sturgeons (3-4 g) in Russia (Bauer et al., 2002). Flavobacterium johnsoniae and Flavobacterium hydatis isolates were associated with disease in cultured Russian sturgeon (Acipenser gueldenstaedtii) in Turkey (Karatas et al., 2010, Timur et al., 2010).

An outbreak of Pseudomonas fluorescens was reported in young (10 g in size) farmed Siberian sturgeon (Acipenser baerii) with high mortality (40\%) in northern Italy (Brunetti et al., 2006).

Outbreaks of mycobacteriosis in reared sturgeons, including Chinese sturgeon (Acipenser sinensis), Russian sturgeon (Acipenser gueldenstaedtii) and Amur sturgeon (Acipenser schrencki), were identified (Zhang et al., 2017, Antuofermo et al., 2014, Righetti et al., 2014).

Several Acinetobacter isolates were detected in both Acipenser gueldenstaedtii and Acipenser baerii involved in the mortality outbreaks caused by NCLDV (Ciuli et al., 2016).

Lesions in Acipenser gueldenstaedtii and Acipenser baerii have been described during natural and experimental infections with Acinetobacter johnsonii and Acinetobacter baumannii (Kozinska et al., 2014).

Streptococcus dysgalactiae, a Gram-positive bacterium, has been isolated from Acipenser schrenckii in China. Haemorrhages, abdominal swelling and ascites have also been reported in cultured sturgeons (Yang and Li, 2009).

Also, Yersinia ruckeri, Flavobacterium columnare, Flavobacterium psychorphilum and Renibacterium salmoninarum have been isolated from sturgeons reared in recirculating aquaculture system (Pelkola et al., 2012).

\section{Parasitic diseases}

Most common parasitic diseases are those in reared young sturgeons caused by ciliates of the genus Trichodina and other genera of the family Urceolariidae. Rarely occurs infections caused by Ichthyophthirius multifilis and Chilodonella cyprini (Bauer et al., 2002). Helminthic diseases of reared sturgeons are very rare in fish farms, although representatives of several species of Monogenea, Trematodes, Cestodes and Nematodes are sometimes found in reared sturgeons (Bauer et al., 2002). 


\section{Other diseases}

Fungal diseases caused by Saprolegniaceae are of great importance, especially during incubation of sturgeon eggs. Mortality of eggs during this period sometimes reaches 70-90\%. Thirteen species of pathogens have been found, including Saprolegnia (seven species), Achlia (two species), Aphanomyces (one species), Dactyunus (two species) and Zeptolognia (one species) (Bauer et al., 2002). Jalilpoor et al. (2006) also isolated Penicillium spp., Fusarium spp., $\mathrm{Mu}$ cor spp. and Saprolegnia sp. from the eggs of Acipenser persicus.

\section{CONCLUSIONS}

The increasing importance of sturgeon farming and international trade in all species of sturgeon worldwide has increased the risk of disseminating specific pathogens and emphasizes the need for adequate diagnostics to prevent the spread of these pathogens. Most infections in natural conditions result in unapparent or mild disease, yet various pathogens can be highly pathogenic in sturgeon aquaculture where transfer of pathogens is facilitated by high densities of naïve hosts. As sturgeon is increasingly being farmed, a better understanding of the pathogens infecting this species is crucial to the development of a sustainable industry.

The majority of disease conditions on sturgeon farms could be significantly reduced if proper attention is paid to good husbandry and the maintenance of optimal environmental conditions, especially water quality.

In conclusion, the wide diversity of pathogens and the numerous movements of live fish and fish products have likely strongly contributed to the spread of infectious agents for years. The transfers of live material need to be better controlled in the future with an aim of improving fish health and hence their commercial and ecological value. Considering the potential of various infectious pathogens to cause severe disease in an aquaculture setting, additional studies are needed to increase the knowledge on the epidemiology of sturgeon diseases. This will help in controlling infections of managed stocks reared for food and also in conservation programs.

\section{ACKNOWLEDGEMENT}

This study was financially supported by a grant from the Ministry of Education, Science and Technology development of the Republic of Serbia, under the project TR31075, TR-31011. 


\section{REFERENCES}

1. Adkison M.A., Cambre M., Hedrick R.P. 1998. Identification of an iridovirus in Russian sturgeon (Acipenser guldenstadi) from northern Europe. Bulletin of the European Association of Fish Pathologists 18, 29-32;

2. Antuofermo E., Pais A., Nuvoli S., Hetzel U., Burrai G.P., Rocca S., Prearo M. 2014. Mycobacterium chelonae associated with tumor-like skin and oral masses in farmed Russian sturgeons (Acipenser gueldenstaedtii). BMC Veterinary Research, 10, 18;

3. Athanassopoulou F., Billinis C., Prapas, T. 2004. Important disease conditions of new cultured species (Acipensergueldestaedi, Mugil sp., Dicentrarchus labrax and Silurus sp., Oreochromis sp.) in intensive freshwater farming conditions in Greece: First incidence of nodavirus infection in Acipenser sp. Disease of Aquatic Organisms 60:241-246;

4. Axén C., Vendramin N., Toffan A. 2018. Outbreak of Mortality Associated with Acipenser Iridovirus European (AcIV-E) Detection in Siberian Sturgeon (Acipenser baerii) Farmed in Sweden. Fishes, 3, 42;

5. Bauer O.N., Pugachev O.N., Voronin V.N. 2002. Study of parasites and disease of sturgeons in Russia: a review. Journal of Applied Ichthyology 18, 420-429;

6. Bigarré L., Lesne M., Lautraite A., Chesneau V., Leroux A., Jamin M., Boitard P.M., Toffan A., Prearo M. Labrut S., Daniel P. 2017. Molecular identification of iridoviruses infecting various sturgeon species in Europe. Journal of Fish Diseases 40(1), 105-118;

7. Bronzi P. and Rosenthal H. 2014. Present and future sturgeon and caviar production and marketing: A global market overview. Journal of Applied Ichthyology, 30, 1536- 1546;

8. Brunetti R., Gasparri F., Marturano S., Prearo M. 2006. Pseudomonas fluorescens infection in farmed Siberian sturgeon (Acipenser baeri). Ittiopatologia, 3, 221-226;

9. Chen M.H., Hung S.W., Shyu C.L., Lin C.C., Liu P.C., Chang C.H., Shia W.Y., Cheng C.F., Lin S.L., Tu C.Y., Lin Y.H., Wang W.S. 2012. Lactococcus lactis subsp. lactis infection in Bester sturgeon, a cultured hybrid of Huso huso $\times$ Acipenser ruthenus, in Taiwan. Research in Veterinary Science 93(2):581-8;

10. Ciulli S., Volpe E., Sirri R., Passalacqua P.L., Cesa Bianchi F., Serratore P., Mandrioli L. 2016. Outbreak of mortality in Russian (Acipenser gueldenstaedtii) and Siberian (Acipenser baerii) sturgeons associated with sturgeon nucleo-cytoplasmatic large DNA virus. Veterinary Microbiology, 191, 27-34; 
11. Clouthier S.C., Vanwalleghem E., Copeland S., Klassen C., Hobbs G., Nielsen O., Anderson E.D. 2013. A new species of nucleo-cytoplasmic large DNA virus (NCLDV) associated with mortalities in Manitoba lake sturgeon Acipenser fulvescens. Disease of Aquatic Organisms 102, 195-209;

12. Clouthier S.C., Van Walleghem E., Anderson E.D. 2015. Sturgeon nucleocytoplasmic large DNA virus phylogeny and PCR tests. Disease of Aquatic Organisms 117:93-106;

13. Clouthier S.C., Anderson E.D., Kurath G., Breytac R. 2018. Molecular systematics of sturgeon nucleocytoplasmic large DNA viruses. Molecular Phylogenetics and Evolution 128, 26-37;

14. Colson P., De Lamballerie X., Yutin N., Asgari S., Bigot Y., Bideshi D., Xiao-Wen C., Federici B., Van Etten J., Koonin E., La Scola B. Raoult D. 2013. "Megavirales", a proposed new order for eukaryotic nucleocytoplasmic large DNA viruses. Archives of Virology 158: 2517;

15. Di J., Zhang S., Huang J., Du H., Zhou Y., Zhou Q., Wei Q. 2018. Isolation and identification of pathogens causing haemorrhagic septicaemia in cultured Chinese sturgeon (Acipenser sinensis). Aquaculture Research 49:3624-3633;

16. Doszpoly A. and Shchelkunov I.S. 2010. Partial genome analysis of Siberian sturgeon alloherpesvirus suggests its close relation to AciHV-2. Acta Veterinaria Hungarica 58, 269-274;

17. Hedrick R.P., Groff J.M., McDowell T., Wingfield W.H. 1990. An iridovirus infection of the integument of the white sturgeon Acipenser transmontanus. Disease of Aquatic Organisms 8, 39-44;

18. Gholamhosseini A., Taghadosi V., Shiry N., Akhlaghi M., Sharifiyazdi H., Soltanian S., Ahmadi N. 2018. First isolation and identification of Aeromonas veronii and Chryseobacterium joostei from reared sturgeons in Fars province, Iran. Veterinary research forum, 9(2), 113-119;

19. Georgiadis M.P., Hedrick R.P., Carpenter T.E. 2001. Factors influencing transmission, onset and severity of out breaks due to white sturgeon iridovirus in a commercial hatchery. Aquaculture, 194: 21-35;

20. Georgiadis M.P., Hedrick R.P., Johnson W.O., Yun S., Gardner I.A. 2000. Risk factors for outbreaks of disease attributable to white sturgeon iridovirus and white sturgeon herpesvirus- 2 at a commercial sturgeon farm. American Journal of Veterinary Research, 61(10), 1232-1240;

21. Hedrick R.P., Speas J., Kent M.L., McDowell T. 1985. Adeno-like virus associated with a disease of cultured white sturgeon (Acipenser transmontanus). Canadian Journal of Fisheries and Aquatic Sciences 42: 1321-1325;

22. Hedrick R.P., McDowell T.S. 1991. Isolation of an epitheliotropic herpesvi- 
rus from white sturgeon. Disease of Aquatic Organisms 11: 49-56;

23. Jalilpoor J., Masouleh A.S., Masoumzadeh M. 2006. Fungal flora in Acipenser persicus eggs with particular emphasis on Saprolegnia sp. (Oomycetes) and mortality during mass incubation at the Shahid Beheshti hatchery. Journal of Applied Ichthyology, 22: 265-268;

24. Karatas D., Ercan T.M., Steinum E., Turgay D., Memis A. 2010. First isolation of a Flavobacterium johnsoniae like bacteria from cultured Russian sturgeon in Turkey. Journal of Animal Veterinary Advances, 9 (14) 1943-1946;

25. Kayis Ş., Er A., Kangel P., Kurtoğlu İ. Z. 2017. Bacterial pathogens and health problems of Acipenser gueldenstaedtii and Acipenser baerii sturgeons reared in the eastern Black Sea region of Turkey. Iranian Journal of Veterinary Research, 18 (1), 18-24;

26. Kelley G.O., Waltzek T.B., McDowell T.S., Yun S.C., LaPatra S.E. Hedrick R.P. 2005. Genetic relationships among herpes-like viruses isolated from sturgeon. Journal of Aquatic Animal Health 17, 297-303;

27. Kempter J., Sadowski J., Schutze H., Fischer U., Dauber M., Fichtner D., Panicz R., Bergmann S.M. 2009. Koi herpes-virus: Do Acipenserid restitution programs pose a threat to carp farms in the disease-free zones? Acta Ichtyologica et Piscatoria 39, 119-126;

28. Kozińska A., Paździor E., Pękala A., Niemczuk, W. 2014. Acinetobacter johnsonii and Acinetobacter baumanii - the emerging fish pathogens. Bulletin of the Veterinary Institute in Pulawy, 58(2), 193-199;

29. Kurobe T., Kelley G.O., Waltzek B., Hedrick R.P. 2008. Revised phylogenetic relationships among herpesviruses isolated from sturgeons. Journal of Aquatic Animal Health 20, 96-102;

30. LaPatra S.E., Groff J.M., Jones G.R., Munn B., Patterson T.L., Holt R.A., Hauck A.K., Hedrick R.P. 1994. Occurrence of white sturgeon iridovirus infections among cultured white sturgeon in the Pacific Northwest. Aquaculture 126, 201-210;

31. LaPatra S.E., Jones G.R., Shewmaker W.D. 1995. Immunological Response of White Sturgeon to a Rhabdovirus of Salmonid Fish [C]. In: Vadim Birstein and William Bemis (eds), The Sturgeon Quarterly, 809;

32. LaPatra S.E., Groff J.M., Keith I., Hogans W.E., Groman D. 2014. Case report: concurrent herpesviral and presumptive iridoviral infection associated with disease in cultured shortnose sturgeon, Acipenser brevirostrum (L.), from the Atlantic coast of Canada. Journal of Fish Diseases 37, 141-147;

33. Ma Z., Yang H., Li T., Luo L., Gao J. 2009. Isolation and identification of pathogenic Aeromonas veronii isolated from infected Siberian sturgeon (Acipenser baerii). Acta Microbiologica Sinica 49(10): 1289-1294; 
34. Mao J., Wano J., Chinchar G.D., Chinchar, V.G. 1999. Molecular characterization of a ranavirus isolated from largemouth bass Microprerus aslmoides. Disease of Aquatic Organisms, 37:107-114;

35. Meng Y., Xiao H.B., Zeng L.B. 2011. Isolation and identification of the hemorrhagic septicemia pathogen from Amur sturgeon, Acipenser schrenckii Journal of Applied Ichthyology 27(2):799-803;

36. Nougayrede P. 1988. Investigation of the distribution of salmonid viruses from the piscicultures in Aquitaine and surrounding regions of France. Bulletin Francais de la Peche et de la Pisciculture 311:134-138;

37. Pelkola K., Vennerström P., Viljamaa-Dirks S., Kuronen H. 2012. Bacterial infections of farmed sturgeon in Finland. Finnish Food Safety Authority Evira; 12: 122-127;

38. Plumb J.A. and Hanson L.A. 2011. Sturgeon viruses. In: Plumb JA, Hanson LA (Eds): Health maintenance and principal microbial diseases of cultured fishes, 3rd edition. Blackwell Publishing pp. 219-225;

39. Raverty S., Hedrick R., Justine H. 2003. Diagnosis of sturgeon iridovirus infection in farmed white sturgeon in British Columbia. Canadian Veterinary Journal, 44 41:327-328;

40. Pospichal A., Piackova V., Pokorova D., Vesely T. 2016. Susceptibility of stone loach (Barbatula barbatula) and hybrids between sterlet (Acipenser ruthenus) and beluga (Huso huso) to cyprinid herpesvirus 3. Veterinarni Medicina, 61: 249-255;

41. Raverty S. and Nikl L. 1999. Sturgeon mortalities along the Harrison River, British Columbia. Animal health center, Newsletter, Diagnosis and Diary. 9, 10-11;

42. Righetti M., Favaro L., Antuofermo E., Caffara M., Nuvoli S., Scanzio T., Prearo M. 2014. Mycobacterium salmoniphilum infection in a farmed Russian sturgeon, Acipenser gueldenstaedtii (Brandt \& Ratzeburg). Journal of Fish Diseases, 37(7), 671-674;

43. Santi M., Pastorino P., Foglini C., Righetti M., Pedron C., Prearo M. 2019. A survey of bacterial infections in sturgeon farming in Italy. Journal of Applied Ichthyology 35:275-282;

44. Soltani M. and Kalbassi M.R. 2001. Protection of Persian surgeon (Acipenser persicus) fingerling against Aeromonas hydrophila septicemia using three different antigens. Bulletin of the European Association of Fish Pathologists 21 (6), 235-240;

45. Shchelkunov I.S., Shchelkunova T.I., Shchelkunov A.I., Kolbasova Y.P., Didenko L.V., Bykovsky A.F. 2009. First detection of a viral agent causing disease in farmed sturgeon in Russia. Diseases of Aquatic Organisms 86, 193-203; 
46. Timur G., Akaylı T., Korun J., Yardımcı E.R.A. 2010. Study on bacterial haemorrhagic septicemia in farmed Young Russian sturgeon in Turkey (Acipencer gueldenstaedtii). Turkish Journal of Fisheries and Aquatic Sciences, 25: 19-27;

47. Vicenova M., Reschova S., Pokorova D., Hulova J., Vesely T. 2011. First detection of pike fry-like rhabdovirus in barbell and spring viraemia of carp virus in sturgeon and pike in aquaculture in the Czech Republic. Diseases of Aquatic Organisms 95, 87-95;

48. Vuillaume A., Brun R., Chene P., Sochon E., Lesel R. 1987. First isolation of Yersinia ruckeri from sturgeon, Acipenser baerii Brandt, in south west of France. Bulletin of the European Association of Fish Pathologists, 7, 18-19;

49. Wang X., Xu L., Wang J., Wang S., Cao H. 2014. Isolation, identification and drug sensitivity of Streptococcus iniae from hybrid sturgeons (Huso dauricus female x Acipenser schrencki male) Acta Microbiologica Sinica Vol. 54 (4), 442-8;

50. Watson L.R., Yun S.C., Groff J.M., Hedrick R.P. 1995. Characteristics and pathogenicity of a novel herpesvirus isolated from adult and subadult white sturgeon Acipenser transmontanus. Diseases of Aquatic Organisms 22, 199-210;

51. Watson L.R., Milani A., Hedrick R.P. 1998. Effects of water temperature on experimentally-induced infections of juvenile white sturgeon Acipenser transmontanus with the white sturgeon iridovirus WSIV. Aquaculture 166, 213-228;

52. Watson L.R., Groff J. M., Hedrick R.P. 1998. Replication and pathogenesis of white sturgeon iridovirus (WSIV) in experimentally infected white sturgeon Acipensertransmontanus juveniles and sturgeon cell lines. Diseases of Aquatic Organisms 32, 173-184;

53. Waltzek T. B., Miller D.L., Gray M.J., Drecktrah B., Briggler J.T., Macconnell B., Hedrick, R. 2014. New disease records for hatchery-reared sturgeon, I, Expansion of frog virus 3 host range into Scaphirhynchus albus. Diseases of Aquatic Organisms, 111(3), 219-227;

54. Williot P., Sabeau L., Gessner J., Arlati G., Bronzi P., Gulyas T., Berni P. 2001. Sturgeon farming in Western Europe: Recent developments and perspectives. Aquatic Living Resources, 14, 367- 374;

55. Xu J., Zeng X., Jiang N., Zhou Y., Zeng L. 2015. Pseudomonas alcaligenes infection and mortality in cultured Chinese sturgeon, Acipenser sinensis. Aquaculture, 446, 37-41;

56. Yang W. and Li A. 2009. Isolation and characterization of Streptococcus dysgalactiae from diseased Acipenser schrenckii. Aquaculture. 294: 14-17; 
57. Zhang Q.Y., Gui J.F. 2012. Atlas of aquatic viruses and viral disease. Beijing: Science press, 256-260;

58. Zhang S.H., Nie P., Shu S.W., Du H., Foo K.L., Yang Y.M., Shao C., Di J., Huang J., Zeng L.B., Wei Q.W. 2017. Mycobacteriosis in cultured F2 generation Chinese sturgeon (Acipenser sinensis) and relevant blood physiological and biochemical indices. Journal of Fishery Sciences of China, 24(1), 136-145.

Submitted: 21.03.2019.

Accepted: 17.06.2019. 